Article

\title{
Upward, Lateral, or Downward? Multiple Perspectives on Migrants' Educational Mobilities
}

\author{
Janina Söhn * and Milena Prekodravac \\ SOFI-Soziologisches Forschungsinstitut Göttingen, Göttingen University, 37085 Göttingen, Germany; \\ E-Mails: janina.soehn@sofi.uni-goettingen.de (J.S.), milena.prekodravac@sofi.uni-goettingen.de (M.P.) \\ * Corresponding author
}

Submitted: 24 August 2020 | Accepted: 6 November 2020 | Published: 18 February 2021

\begin{abstract}
Education is a major component of individuals' social status in terms of self-positioning and economic opportunities. Migrants' qualifications from abroad are often devalued by employers or state institutions. One option to react to such a lack of recognition is the gaining of institutionalized cultural capital in the receiving society. Comparing levels of education attained before and after migration, migrants may move in an upward, lateral, or downward direction. Our study investigates the vertical dimension of transnational educational mobility from multiple perspectives. First, our quantitative analysis of the NEPS (the German National Educational Panel Study) relates the levels of pre- and post-migration education. We critically reflect on how respective results on educational mobility depend on how respondents sort their foreign education into the German system of educational categories and hierarchies used in the survey questionnaire. Second, our qualitative analysis sheds light on several dimensions of migrants' subjective views and how their educational biographies interact with institutional settings in the receiving society. Exemplarily presented in-depth interviews focus on migrants who pursued educational programs in order to be able to return to the occupations (nursing and economics) they had been trained for abroad, but for which they were denied recognition in Germany. Our findings emphasize that post-migration education is highly ambivalent in terms of in- and exclusion. Individual migrants are caught in the structural tension between academic education as a rather globalized institution and nationally specific educational programs and hierarchies which are often incompatible across borders.
\end{abstract}

\section{Keywords}

educational mobility; educational participation; mixed methods; migration; non-recognition; post-migration education; vocational training

\section{Issue}

This article is part of the issue "Migration and Unequal Social Positions in a Transnational Perspective" edited by Thomas Faist (Bielefeld University, Germany).

(C) 2021 by the authors; licensee Cogitatio (Lisbon, Portugal). This article is licensed under a Creative Commons Attribution 4.0 International License (CC BY).

\section{Introduction}

How is migration across national borders linked to social positions with regard to both the migrant's 'objective' social status and to their 'subjective' status, that is, according to their own perceptions and evaluations? This broad question aims at one of the core objectives of this special issue. Our article seeks to contribute to answering it by focusing on education. Social stratification theory views education as an intrinsic part of adults' social status and a strong influence on occupational status and potential income within the labour market (e.g., Di Stasio, Bol, \& van de Werfhorst, 2016). Usually, full-time education biographically precedes entry into the working life. Some migrants, however, take the detour of going back to school with the intention of reaching their occupational goals thereafter. With Germany as the receiving country in our case study, this article's general research question looks into this phenomenon of post-migration educational participation: When individuals who migrate 
as adults, and hence beyond the age of compulsory education, decide to attend an educational program in the immigration country, how do their pre- and postmigration education relate to one another? How does transnational educational positioning function?

Post-migration education as such-participation in, e.g., tertiary education, full-scale vocational qualification programs, or non-formal occupational training coursesis experienced by a substantial minority of about one in four adult migrants in Germany (Liebau \& Romiti, 2014 , p. 14; Söhn, 2016, p. 206). Among educationally active migrants, as we call them, $29 \%$ gained a university degree, $51 \%$ finished an apprenticeship and $17 \%$ a vocational school program (Liebau \& Salikutluk, 2016, p. 737; on recent refugees in Germany see Bonin et al., 2020, pp. 88, 101, 120).

One major reason for adult migrants investing in education within the receiving country is the devaluation of their credentials gained abroad and the economic and occupational downward mobility encountered or feared due to this non-recognition (e.g., Adamuti-Trache, 2011). This is the group this article particularly focusses on. Other migrants use new educational opportunities they did not have in their home country due to war, discrimination, or under-developed educational institutions. Yet others simply continue their educational career in the new country as planned (Szewczyk, 2014). Post-migration education hinges on prerequisites: Advanced knowledge of the official language is usually a basic condition for attending mainstream educational programs. In addition, previous research has shown that factors increasing the likelihood of post-migration education include: pre-migration academic or upper-secondary school education, having been educationally active shortly before migration, being young, being a recent arrival, having favourable legal status, not having children, aiming to work in the health sector, and having a higher household income (Adamuti-Trache, 2011, p. 75; Söhn, 2016, p. 207; van Tubergen \& van de Werfhorst, 2007, p. 890).

Adult immigrants who participate in education not only in their country of origin but also in the receiving country (and possibly others too) display, as we define them, transnational educational biographies (using 'transnational' for migrants' point of view and 'international' for that of nation states like Faist, 2016, p. 235). The mobility of such migrants from one national educational system into another, both of which display a stratified structure, necessarily has a vertical dimension. Speaking in the very abstract, this move between two hierarchies has to be either upward-as in the idea of an actual educational 'career'-lateral, or downward, i.e., there are three basic subcategories of vertical mobility. We refrain from starting with a fixed assumption when transnational educational mobility 'objectively' shows an upward, lateral, or downward direction. Instead, we will theoretically and methodologically reflect on which and whose perspectives evaluate and construct positions in educational hierarchies-especially that between tertiary education and non-academic vocational training - and their relation in partly contradictory manners. These multiple frames of reference regarding sending and host societies (Faist, 2016, p. 325; Rye, 2019) as well as globalized institutions (Schofer \& Meyer, 2005) are differently embedded in the quantitative and qualitative data we present here. Given this conceptual thrust of self-reflection in our article, the empirical analyses serve as an exemplary opportunity to demonstrate this multiplicity of perspectives rather than to comprehensively study the phenomenon of transnational educational mobility in its entire historical and institutional complexity.

As a unique quantitative-empirical contribution, we use retrospective life course data from the NEPS (the German National Educational Panel Study) to relate the levels of pre- and post-migration education. What assumptions do we as researchers apply when we reconstruct the vertical dimension of migrants' transnational educational mobility this way? The qualitative part of our empirical analysis zooms in on specific groups of migrants who-by the definition applied in our statistical analysis-fall into the subcategory of lateral educational mobility. We will analyse in-depth interviews with migrants who participated in (1) a course for nurses, a licensed occupation requiring non-academic training in Germany, or (2) a further training course for migrants with a tertiary qualification in the non-regulated field of economics. How did migrants themselves perceive the vertical nature of their transnational educational mobility? How does the way their foreign qualifications became devalued relate to the program they attended, to their educational biographies, and their occupational ones?

After this introduction, Section 2 theoretically elaborates on the nexus of migrants' educational trajectories with educational and labour-market institutions in the country of migration, the frequent mismatch between different, hierarchically stratified national educational systems, and the institutional specifics in the case of Germany. Section 3 juxtaposes the different migrant cohorts of our quantitative and qualitative samples. We critically discuss the difficulties of constructing a mixed-methods model in which a qualitative sample of migrants was actually nested into a qualitative one. Section 4 describes the quantitative database, the operationalization of levels of pre- and post-migration education and their relation and presents the respective descriptive findings. Section 5 switches to qualitative results and the interviewees' perspective on their transnational educational biographies.

\section{Theoretical Reflections, Previous Findings and Institutional Structures of the German Case}

\subsection{Non-Recognition of Migrants' Qualification from Abroad as a Driver for Post-Migration Education}

Educational certificates are often a precondition for accessing specific occupations and corresponding 
positions within the income hierarchies of firms and in the labour market more generally. The meritocratic ideal in modern societies in fact legitimizes the correlation between a higher level of education and higher socioeconomic status (Themelis, 2008, pp. 429-431). Empirically, the strength of the link between education and occupation attained is not absolute but depends on the occupational field and varies substantially within and across countries. In international comparison, Germany features a relatively tight education-occupation linkage (DiPrete, Eller, Bol, \& van de Werfhorst, 2017).

For many migrants, this linkage is fragile, if not broken. Being over-educated (Aleksynska \& Tritah, 2013; Davia, McGuinness, \& O'Connell, 2017) as well as becoming and remaining unemployed (Reyneri \& Fullin, 2011) is much more widespread among migrants than natives. While migrants without formal qualifications bear the double burden of migration- and education-related disadvantages, many qualified migrants are faced with a lack of or insufficient worth being given to their foreign educational certificates and work experience. In Bourdieu's terms, native employers, state institutions, and/or professional self-organizations may not recognize the value of the institutionalized and embodied cultural capital accumulated in migrants' countries of origin (Nohl, Schittenhelm, Schmidtke, \& Weiß, 2014, pp. 42-47). This devaluation takes place in an asymmetric power relation with native actors in a superior position to the individual migrant. Such processes are inherently embedded in a world of nation states with nationally constituted education systems, global hierarchies between rich and poor countries, as well as control of migration through national citizenship and migration policy (e.g., Schittenhelm, 2018).

In reaction to such experienced or feared downgrading, migrants may attain new cultural capital in the country of migration, hoping to 'mend' the linkage between education and positions attainable in the labour market (Adamuti-Trache, 2011, pp. 75-76; Nohl et al., 2014, pp. 25-26, 33; Söhn, 2016, pp. 198-199). Certificates handed out by native institutions should be more readily appreciated by sending productivity signals (Spence, 1973) which employers decipher more easily or more willingly than foreign credentials alone. Indeed, postmigration education substantially increases prospects within the labour market (Kanas \& van Tubergen, 2009).

The risk of non-recognition and the corresponding potential need to go back to school varies according to several institutional logics: First, some skills, such as those linked to inherently national occupations (e.g., teachers for national history), are hard to transfer (Weiß, 2005, p. 716) or are simply not needed (e.g., fishery in a country without access to the sea). Second, a high grade of occupational regulation implies occupational closure-a generator of social inequality, as conceptualized already by Weber (1922/1980, pp. 23, 202). Occupations which are closely bound to government functions such as the juridical system, the police, educa- tional or health professions require state licenses (Haupt, 2016). Migrants with foreign training in an occupation which is licensed in the receiving country either have to take obligatory courses or exams to be allowed to pursue their profession. Or, third, laws declare the foreign training as equivalent to the native one, as is the case when EU-citizens work in other EU countries (see Adamo \& Binder, 2018). For instance, nurses trained in EU-member states may, with few exceptions, practice their profession without that extra hurdle (BMBF, 2020, p. 30). The problem of (non-)recognition of foreign credentials thus has a strong political component.

\subsection{Moving from One Stratified Educational System into Another: The Vertical Dimension of Transnational Education Mobility}

Educational mobility, like occupational mobility, has two dimensions: a vertical and horizontal (Sacchia, Kriesib, \& Buchmannca, 2016, p. 11). Referring to the division of labour, the horizontal dimension differentiates content or specialization, e.g., psychology versus linguistics. In this article, we cannot systematically deal with this horizontal dimension of switching educational fields but dedicate the remaining elaborations to the vertical dimension.

National educational systems are intrinsically stratified, with elementary education at the bottom and university education at the top with vocational training usually located below the latter. Vocational training, including apprenticeships, is here defined as non-academic, i.e., not part of higher, tertiary education. This categorical educational hierarchy is enshrined in scientific-but also politically negotiated-classifications developed for international comparisons, such as the International Standard Classification of Education (ISCED), which in essence presumes a rough equivalency of these abstract educational categories across countries and their particularities (Bohlinger, 2012).

Now, if the educational hierarchical structure in country $A$ and $B$ were identical and mutually acknowledged as such, determining the vertical direction of migrants' educational mobility would be fairly unproblematic-as it is for natives moving within their own national education system. Obviously, this is not automatically the case. Two structural characteristics make Germany's education system a rare type, with only Austria and Switzerland showing strong resemblance: first, the secondary-school system with early selection into stratified school types, second, the non-academic vocational training system. As we will show, individual migrants bear the brunt of the institutional mismatch between countries.

Many countries have comprehensive secondary schools and require additional tests or entrance exams to begin tertiary education. But in Germany, only the baccalaureate (Abitur) attained in upper-tier secondary schools gives general access to universities. If migrants only have an upper-secondary school degree attained 
after 11 rather than 12 or 13 years as in Germany, and if they have not yet started tertiary education in their home country, German educational authorities will classify such a school degree as not equivalent to a German baccalaureate. They would have to attend a preparatory course before moving up to higher education (Schammann \& Younso, 2016).

As to Germany's full-scale vocational training, most of these highly standardized non-academic programs take place in the so-called dual system of apprenticeships. Apprentices are employed by companies (for a small salary); learning alternates between on-the-job training within the firm and in a vocational school, over three years (Protsch \& Solga, 2016). The same applies to, e.g., health-related occupations requiring non-academic training which is formally called 'schoolbased' in Germany but also involves long internships, e.g., as nursing students in hospitals. As most other countries in the world have only school-based vocational training or merely informal learning on the job, most migrants with non-academic vocational qualifications cannot prove that their formal training includes sufficiently long periods of in-firm learning as is typical in Germany. Due to this institutional incongruence, German institutions take their occupational standards as their yardstick and often refuse to recognize such foreign vocational degrees as fully equivalent (Sommer, 2015, p. 277)-more often than they do foreign academic certificates (Kogan, 2012, p. 78). This German institutional perspective is mirrored in controversies about how the international ISCED categorizes national educational programs: Germany repeatedly complains that its vocational training in the dual system is categorized as too low, namely only as post-secondary non-tertiary, and hence is placed below 'real' tertiary programs (Bohlinger, 2012, pp. 18-19).

In contrast to nationally specific vocational training systems, university education has become a globalized institution and norm, as Schofer and Meyer (2005) argue. This globalized norm includes the idea that individuals with tertiary education are meant for high occupational positions (Schofer \& Meyer, 2005, pp. 900-917), higher positions than those of persons with, e.g., 'only' vocational training (for the corresponding strong empirical correlation regarding income see Autorengruppe Bildungsberichterstattung, 2018, p. 205). The European Bologna Process explicitly aims at a (formal) standardization and mutual recognition of Bachelor and Master's degrees across state borders. However, this transnational recognition is mainly limited to moving within the system of higher education-a close linkage to occupational positions in other national labour markets is not guaranteed.

There is only little empirical research about migrants' vertical educational mobility. Upward mobility regularly takes place between academic programs, e.g., from a master's degree gained in the home country to a PhD in another. Such biographies are well embedded into the institutions of the Bologna Process and thoroughly planned by the individual (on Polish graduates in the UK see Szewczyk, 2014). Downward educational mobility is close to unheard of among natives. Yet, migration research has highlighted such cases, such as the academically trained engineer attending a course on IT administration (Nohl, 2010, p. 162; on a Bosnian journalist going back to Swedish secondary school see Povrzanović Frykman, 2009). Immigrants experience this as humiliating but still prove their tenacity by passing through respective programs. Bonin et al. $(2020$, p. 89$)$ show that one in five refugees who participated in vocational training in Germany had already gained a vocational degree before their flight.

\section{Transnational Educational Mobility Analysed with Quantitative and Qualitative Data: Challenges of Mixing Methods}

We refrain from calling the quantitative and qualitative data presented here a proper mixed-methods research design. Ideally, the qualitative sample for indepth interviews should be drawn from a representative survey, as Tucci, Fröhlich, and Stock (2021) show with the Socio-Economic Panel (SOEP), which offers this unique opportunity. In the context of our larger research project, we first chose the nationally representative NEPS because it contains more encompassing retrospective life course data in the field of education (and on further occupational training in particular) than the SOEP. With this choice of quantitative data necessary for the research topic, other constrictions follow. We use the scientific use file (SUF) of first survey wave (2009-2010) and new participants of the third wave (2011-2012) of Starting Cohort 6 (SC6, "Adult Education and Lifelong Learning"; see Blossfeld, Roßbach, \& von Maurice, 2011).

The NEPS, like the SOEP, gathers retrospective lifecourse data the first time interviewees take part. Despite subsequent panel waves, the first wave with that first interview remains the relevant one here. In order to study the first six years in Germany, the survey participant has to have immigrated at least six years before the first interview. Thus, the immigration cohorts studied are, unavoidably, historically 'old.' The years of arrival stretch from 1963 to 2006 (mean: 1991; all means and percentages reported from this section onward are statistically weighted results of our quantitative analysis). Two-thirds came from Eastern Europe, one fifth from outside of Europe.

In contrast, our in-depth interviews, conducted between 2016 and 2018, aimed to get hold of migrants during their educational participation with correspondingly fresh memories about what led them there and how they perceived it. As post-immigration education typically takes place within the first few years of arrival (see Söhn, 2019, p. 51), members of our qualitative sample unsurprisingly had come to Germany only between 2000 and 2016 (from a range of EU- and non-EU countries). 
Hence, there is little historical overlap between the immigrant cohorts analysed qualitatively and quantitatively. But, without downplaying historical changes, the structural problem of institutional incongruence between the German system of education and that of most other countries of origin, as explained above, has remained essentially the same. Such mismatches and the proclamation or denial of educational achievements' equivalency are at the heart of the methodological self-reflection in the course of presenting empirical results.

The qualitative data puts individuals' perceptions of educational positions and social status at the forefront. Their educational biographies-as social positioning in action (Deppermann, 2015)-results from individual strategies intertwined with institutional regulations and actors of, e.g., educational institutions, public administration, and the labour market. Going beyond previous qualitative insights into transnational educational biographies (see last paragraph of Section 3), our qualitative analysis will investigate the complexities behind cases of seemingly 'lateral' mobility: Migrants visited an educational program located in the same occupational field as that in which they had been trained for before coming to Germany. This type of educational participation has become increasingly likely due to the Law to Improve the Assessment and Recognition of Professional and Vocational Education and Training Qualifications Acquired Abroad (the full title of the Federal Recognition Act) adopted in 2012. Holders of non-German certificates who get a partial recognition of equivalency with German diplomas have the right to-and have toattend an educational program that leads to full recognition, often subsidized by the public employment service (e.g., Sommer, 2015). It is important to note, however, that this legislative package only gives the right to have non-German qualifications examined for equivalency-it does not automatically provide full recognition.

\section{Re-Constructing the Extent of Migrants' Upward, Lateral, and Downward Educational Mobility with Quantitative Data}

\subsection{Operationalizing Education in the Context of Migration Critically Reflected Upon}

The target population of educationally active immigrants ( $N=313$ ) is defined as individuals who spent at least one month in full-time education within their first six years in Germany and who migrated as adults, with 26 years on average-an age when most natives have already transitioned to work. Information on the pre-and post-immigration level of education stems from the last episode of education reported prior moving to Germany and the first episode of education following arrival. We chose the first educational episode in Germany rather the final degree attained because, regarding the problem of non-recognition, it is relevant how much migrants had to move down the educational ladder.
Using survey data about the kind of education after migrating is methodologically unproblematic, as the participants recognize the label of 'their' program or certificate in the questionnaire from their own educational participation in Germany. Post-migration education covers any kind of academic training, non-academic full-scale vocational training as well as shorter full-time further occupational training leading to a 'license' (e.g., welding, IT administration; see Kruppe \& Trepesch, 2017, pp. 11-13), pre-vocational programs and secondary-school education.

Regarding the educational career outside of Germany, immigrated respondents of the NEPS and any national survey must try to fit the education attained abroad into the survey's standardized answer categories, which mirror the German education system. As data users, we have to accept how survey participants resolve this 'transnational' sorting. Hence, the quantitative analysis takes on the migrant's view of educational equivalency rather than that of German institutions or employers which actually deal with or could potentially deal with an evaluation of foreign qualifications.

Our variable of the pre-migration level of education used for Figure 1 simplifies and thus smooths out numerous educational subcategories by only distinguishing (1) secondary-school education at most, (2) non-academic vocational qualifications, and (3) tertiary qualifications as the highest level (college, university, PhD). In order to determine the vertical relation of pre- and post-migration levels of education, we used much more differentiated information than these three levels. For instance, four migrants with a PhD started studying again at a German university and were categorized as downwardly mobile. Three people with only low-secondary schooling were upwardly mobile by attaining a mid-level secondary school degree. Illustrating lateral mobility, 37 individuals who attained a non-academic vocational degree abroad started an apprenticeship after migrating. If information on the content of further occupational training was available and could be related to pre-migration information, this was also used to determine the subcategory of vertical educational mobility. For instance, an experienced cook attending a nutrition course was labelled laterally mobile; a vet learning tiling took a downward trajectory. Cases with no such information were sorted into a fourth category: further occupational training with an undetermined direction of vertical mobility.

The NEPS allows a small, yet unique double-check of how respondents fit their foreign education into the German category system: Among respondents from the former Soviet Union in our NEPS sample, 51 chose a questionnaire translated into Russian and answered the additional question about their pre-migration level of education according to the former Soviet education system. Cross-tabulating these answers with our regular threecategory variable of pre-migration education, we see, for instance, that fourteen individuals gained the certificate 
of an ex-Soviet "school for continuing vocational training, Bachelor" (LIfBi, 2016, p. 686, as translated in the English version of the NEPS). In the 'German' operationalization of pre-migration education, seven of these fourteen are categorized as having attained vocational education, four as only being school-trained, and three as being academically trained. In comparison to this seeming randomness, nine out of ten people who reached tertiary education in the former Soviet Union end up in the 'correct' corresponding German category. In conclusion, the institutional incongruence of national educational systems cannot be solved by standardized surveys, but a 'valid' perception of transnational equivalency seems more easily achievable for academic training. This underlines the notion of tertiary education as a globalized institution (Schofer \& Meyer, 2005).

\subsection{Quantitative Results}

Before arriving in Germany, $37 \%$ of educationally active adult migrants studied with the NEPS had attained secondary education at most, $34 \%$ non-academic vocational qualifications, and $30 \%$ tertiary education. $78 \%$ finished their last educational episode before migration with a formal certificate. Within the observed first six years in Germany, the migrants spent 26 months in education on average, and it took 20 months (mean) until the first educational episode, most often transitioning from non-employment and into work thereafter (see also Söhn, 2016, p. 203). 18\% started programs at universities, $27 \%$ vocational training, $13 \%$ pre-vocational programs, $5 \%$ secondary schooling, and $36 \%$ further occupational training of various sorts.

Relating pre- and post-migration levels of education, Figure 1 summarizes the main results on the vertical dimension of transnational educational mobility: $28 \%$ experienced transnational upward mobility, $28 \%$ lateral mobility, and $25 \%$ downward mobility, with the remaining $19 \%$ participating in further training courses for which we could not determine the vertical direction. This distribution varies tremendously when differentiated by the educational level attained abroad. For migrants without qualifications beyond secondary education, it was very common (62\%) to move up by starting any kind of post-secondary qualification. On the other end of the spectrum, academically trained migrants have few upward steps remaining (e.g., a PhD) but can fall quite deeply: $44 \%$ of them moved down the educational ladder by, e.g., beginning an apprenticeship; 38\% studied a new subject at a German university (lateral). Migrants with non-academic vocational qualifications from abroad are situated in between, but they more closely resemble those with tertiary education, especially regarding the fairly small percentage of the upwardly mobile (11\%). The largest subgroup (47\%) within the vocationally trained migrants experienced a lateral move.

Among all migrants who showed lateral mobilitythe group the ensuing qualitative findings will focus on $-41 \%$ had attained tertiary education before migration and $56 \%$ non-academic vocational one. The types of educational program attended in Germany were distributed evenly across tertiary education, full-scale vocational qualification, and further occupational training.

Compared to the average distribution across the types of vertical educational mobility, lateral and downward mobility is overrepresented among migrants arriving between 1997 and 2006 by eight and six percentage points, respectively. This is not a proper projection onto more recent migrant cohorts. But in all likelihood, these phenomena still exist-as they do for respondents in our qualitative sample.

\section{5. 'Lateral' Mobility as Seen by Subjects Navigating within Institutional Frameworks-Qualitative Results}

\subsection{The Methodological Choice of Occupation-Specific Educational Programs: Contextualizing the Selected Cases}

Within the context of our larger research project, we recruited interviewees attending occupation-specific educational programs. These programs systematically varied by the academic versus non-academic level (according to the German categorization) as well as by whether practising the occupation required a state license or not (for an overview of the whole qualita-

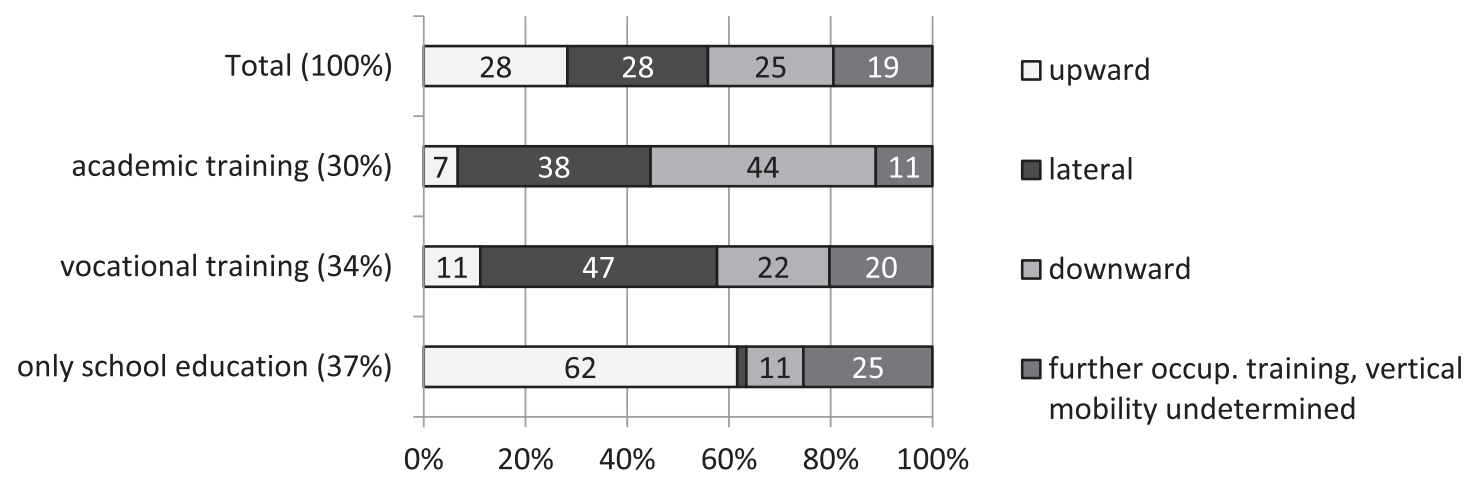

Figure 1. Vertical direction of transnational educational mobility by pre-migration level of education. Source: NEPS (2020). Notes: authors' calculation; $\mathrm{N}=313$; weighted percentages. 
tive sample see Prekodravac, 2020; on licensed academic professions like doctors see also Nohl et al., 2014, pp. 77-83). In the following, we present exemplary cases of (1) nurses and (2) economists.

Nursing in Germany requires training categorized as non-academic which leads to the obligatory license to practice. Qualifications from non-EU-countries require formal evaluation of equivalency (BMBF, 2020, p. 30). In our interviewees' cases of partial equivalency, they were obliged to attend a 1-year recognition course (Anerkennungslehrgang) which included theory lessons on nursing and internships, and which lead to a full professional license as nurses.

Tertiary degrees in the field of economics and business administration offer access to a wide range of occupational positions in Germany, which are usually non-licensed and are on the managerial level. The oneyear preparatory course (Brückenkurs) our interviewees attended targeted migrants (from both EU and non-EU countries) who had gained academic diplomas in this field abroad. The course aimed at easing labour market entry by teaching soft skills and the German cultural specificities of this occupational field.

Both programs explicitly referred to 'foreign qualifications' and addressed migrants who were not yet working in their original profession. Similar to the NEPS, implicit selection criteria came into play. The interviewees' German had to be sufficient (linguistic levels B2 to C1) and they needed a secure residence status in order to participate. Given their age at migration to Germany (between 25 and 42), many already had prior work experience within their profession, yet some (among the economists) did not, having only worked in precarious jobs or having come to Germany immediately after finishing their education.

We recruited our 27 interviewees by first contacting the educational institution which then gave permission for us to ask participants to volunteer for an interview. Using a narrative-biographical approach, we asked interviewees-with a special but not exclusive focus on education-to tell us about their lives before they migrated, their experiences in Germany, and future plans. We analysed the interviews using reconstructive methodology (Deppermann, 2015; Rosenthal, 2018). The following section offers some exemplary snapshots of four (anonymized) biographical narrations in order to illustrate aspects relevant for this article's research questions.

\subsection{Differing Institutional Sorting: Vocational versus Academic Qualification}

A participant of the nursing recognition course, Rafaela, attained a Master's degree in Brazil and became a nursing-ward manager in a penal institution. Rafaela moved to Germany in 2015 because of her German husband, who encouraged her to continue her career as a nurse. Rafaela attended counselling on occupational recognition and received information on her options and the course. She describes this situation as emotionally devastating: "I was very sad." She underlined that her previous education was "not an apprenticeship, it's a university program." Rafaela faced formal devaluation of her academic studies because German regulations categorize nursing as requiring non-academic vocational training (for this conflictual phenomenon from the point of view of non-academically trained native nurses in German hospitals see Pütz, Kontos, Larsen, Rand, \& Ruokonen-Engler, 2019). Had Rafaela participated in the NEPS and categorized her pre-immigration education according to her own understanding, she would have fallen into the category of downward mobility. By contrast, her case appears as one of lateral mobility from the German institutional point of view due to her having remained within the same occupation.

The problematic relationship between a foreign qualification and the German institution of 'dual' vocational training came up in the narratives of the economists, too. Ana had attained a Master's degree in economics and informatics in Bulgaria. As she could not find employment in her professional field, inspired by an acquaintance, she went to Germany in 2014. There, she only managed to get a job in the logistics sector, far below her qualification due to informal devaluation of her credentials within the labour market. She learned about apprenticeships but insisted in the interview that her Bachelor's degree alone took one year longer than an apprenticeship in Germany. She implicitly appealed to international standards of educational ranking as Rafaela did. Yet, she also considered that her lack of an in-firm internship back in Bulgaria was a hurdle in the German labour market because such on-the-job learning is an integral and highly valued part of Germany's dual vocational training. Ana countered the symbolic downgrading of her credentials in the labour market by attending the preparatory course explicitly aimed at immigrants with academic training. Still, there is the potential that courses such as these might unintentionally stigmatize participants as holders of devalued foreign degrees, despite their intention to overcome this very problem of non-recognition.

The categorization of academic versus German-type vocational training functions as a crucial point of reference but with different impacts-informal and institutionalized devaluation in Ana's and Rafaela's case, respectively-depending on the occupation aimed at after arrival.

\subsection{Differing Tasks: Downgrading of Occupational Content within an Occupational Field}

Mrs. Miler finished vocational training in nursing during the 1980s in the Soviet Union. She worked in what is now Ukraine for several years, then went to Libya where she practised her profession for three years. The transnational cultural capital attained helped her to find a highly prestigious job in a private clinic back in Ukraine. There, she met her partner, who lived in Germany, and decided 
to follow him in 2008. Nine years after her arrival, having attended several German language courses and having taken care of her German-born child who suffered from a chronic illness, she finally attended the recognition course for nurses.

Given that both her qualification from abroad and the course in Germany refer to non-academic vocational training, the operationalization used in the quantitative analyses and German authorities would categorize Mrs. Miler as a clear case of lateral mobility. Yet, underneath this label and in addition to the insufficient recognition of year-long work experience as a trained nurse, she had to undergo a subtler downgrading. Mrs. Miler became confronted with the fact that, compared to nursing in her country of origin, this occupation entailed less autonomy regarding medical decisions and the scheduling of one's own duties in Germany. Furthermore, she learned that nurses in German hospitals were expected to perform physically demanding tasks such as washing and feeding patients. Activities which had been reserved for nursing assistants in her country of origin and were judged as being 'below' their qualifications by Mrs. Miler and other participants of the recognition course. They experienced differences in nationally specific institutional structures: Regarding tasks, the occupation labelled as 'nurse' is sorted differently into the occupational hierarchy across countries, in this case into a lower position in Germany than the country of origin.

\subsection{Necessities and Motivations for Attending the Educational Programs}

While the recognition course was obligatory in order to work as a nurse again, the preparatory course for economists was voluntary. Tatyana gained a Bachelor's degree in Management in Latvia. She moved to Germany in 2014 and found badly paid work as a cook, a non-academic occupation she had been trained for before attending college. Applications for positions as an economist remained unsuccessful, and so Tatyana became determined "to do more" and to go back to school. At one point, she wanted to start vocational re-training as a business clerk (i.e., accepting educational downward mobility), yet the public employment service denied financial support. Later, she successfully fought the administration and had them pay the fees of the preparatory course she attended when we met her. Tatyana's motivation to take part was driven by a wish for improvement on different levels: First, she wanted to overwrite her previous qualification as a cook and make her academic training salient for potential employers. Secondly, she saw a need to acquire tools to assert her skills vis-à-vis employers as well as the employment service.

Participants of both types appreciated the 'side effect' of practising and improving their German by attending the programs. The occupational know-how of participants, however, appears to have remained essen- tially unchanged. The main motivation of attending the program was to eventually symbolically translate existing occupational knowledge into a real opportunity to put it into practice in a workplace. The chances of reaching this final goal varied. The nurses were aware of the high demand for licensed nurses on the German labour market and hence of good occupational prospects after finishing their course successfully. The economists' preparatory course only led to a non-formal certificate of attendance. Despite the participants' efforts to demonstrate their commitment to economic integration, there was a lack of certainty over whether employers would indeed interpret their participation in the program as a positive symbolic signal.

\section{Conclusion}

Our contribution on education attained before and after migration started with the observation that education is an inherent and influential part of individuals' socioeconomic status. Indeed, we have been able to show that educational participation after arrival can be a strategy of social positioning which seeks to prevent "declassing" (Rye, 2019, p. 36) and economic marginalization due to insufficient recognition of foreign credentials. Post-immigration education aims at 'mending' the link between educational attainment and occupational positions-a link which the modern ideology of meritocracy (Themelis, 2008) promises but the devaluation of foreign credentials often breaks (Nohl et al., 2014).

Our research questions on how pre- and postmigration education relate to one another and how this relation is re-constructed, perceived, and valued from different perspectives in our quantitative and qualitative data have led to answers on two levels: first, one of methodological meta-reflection on categorizing positions in educational and occupational hierarchies when one must take into account multiple (national) frames of reference; and the second, which relates to the level of empirical results.

As to the first, the multiple perspectives on the vertical dimension of transnational educational mobility included the views of migrants who filled out a standardized questionnaire or narrated their educational experience in in-depth biographical interviews, of native institutions evaluating foreign certificates, and of the researchers who operate with educational classifications or deconstruct seemingly obvious educational categories. Overall, there is no 'objective' way to determine educational equivalency or the vertical direction of mobility, but research should be transparent about the underlying reference.

As data users of the standardized German NEPS, we had no other option but to accept the immigrant respondents' perceptions of how they thought their educational attainment from abroad should be sorted into the system of German educational categories, which cannot be entirely matched with those of other coun- 
tries. A unique cross-check with a survey question on Ex-Soviet educational schooling for some respondents from this region made it possible to reveal that it was only respondents with pre-migration tertiary education (but not those with less schooling) who were easily able to choose the 'correct' educational category in the German classification system. This transnational 'validity' of academic training as a globalized institution (Schofer \& Meyer, 2005) also became apparent in our interviews when both an economist with a university diploma from Bulgaria (which was not valued by the German firms she had applied to in vain) and a nurse with a Master's Degree from Brazil (whose training had been devalued by German institutional regulations). Each insisted on the academic level of their original training. These migrants implicitly referred to the global superiority of tertiary education over non-academic vocational training as it is indeed scientifically enshrined in the educational hierarchy within the ISCED, an educational classification meant for international comparison. The analytical evaluations of transnational educational equivalencies mirrored in both the NEPS and the interviewed migrants' own perspective contrast with the real-life downgrading by native-German actors as reported in our in-depth interviews and, e.g., Sommer's (2015) institutional analysis. As "the location of migrants in the spaces of class" are characterized by "multilocalities, inconsistencies and instabilities" (Rye, 2019, pp. 29-30), so do migrants' educational positions and the value given to their cultural capital vary with space and time.

Provided that the potential and possibly more 'restrictive' perspective of German institutions on the NEPS respondents' pre-migration level of education remains unknown, longitudinal life-course data of the NEPS gave us the exceptional opportunity to relate the levels of pre- and post-immigration education. We presented respective first-time results on migrants who had arrived as adults until the mid-2000s and participated in education within their first six years in Germany. Upward mobility was most often experienced by the large majority of those with only a pre-migration education up to secondary school level. Immigrants who step up the educational ladder should get more attention in an overall assessment of migrants' societal participation. In contrast, almost half among those with foreign vocational training remained on the non-academic level of post-secondary education. The largest subgroup among migrants with tertiary education from abroad moved downward to non-academic vocational training in Germany. This very strong correlation - the higher the pre-migration level of education, the greater the risk of educational downward mobility among migrants-is remarkable, particularly given that educational downward moves are virtually unheard of among natives.

Furthermore, migrants remaining on roughly the same educational level (the lateral subcategory) may often enrol in a program because of previous institutionalized or informal devaluations of their foreign educa- tional credentials and work experience. In our qualitative study, this was clearly the case for both the nurses (with academic or vocational training from abroad) and the economists (with foreign tertiary degrees). Both groups participated in courses in order to remain within their fields and to find adequate employment. In addition, their narration disclosed subtler occupational downgrading. Nursing in Germany is categorized as requiring only non-academic vocational training and, in international comparison, is located at a relatively lower position in the occupational hierarchy regarding tasks, authority, and autonomy in the workplace. Hence, the nurses had to deal with more menial tasks (washing and feeding patients) which they would have delegated to nursing assistants in their countries of origin. A participant with a Master's in economics was told in her previous unsuccessful job search that not having done an in-firm internship, a highly valued integral part of the German dual vocational training system, was a major hurdle. Her softskill course, aimed at holders of non-German tertiary degrees, did not include an internship.

Apart from being able to practice and improve their German language skills in educational programs and gaining some knowledge of informal cultural norms within their occupational field, the participants' substantial occupational expertise seemed to have remained essentially unaltered. The main purpose of educational participation is the symbolical translation of their cultural capital into the German context. For nurses, it eventually led to a full nursing license, but in the case of the economists, it only led to a non-formal certificate of attendance-a much less clear signal for future job applications. Altogether, post-migration educational participation comprised a high ambivalence of in-and exclusionary elements.

Due to data limitations, we could not explore the horizontal dimension of changes between educationaloccupational fields (e.g., from miner to auto mechanic) in transnational educational biographies. Furthermore, there is a lack of published qualitative pretests on how immigrant respondents actually perceive and fill out standardized questionnaires including questions on education and occupation in regular surveys. Finally, our analysis was clearly limited in case numbers and in giving a historically comprehensive empirical picture, as a historical gap in the immigrant cohorts under analysis could not be avoided with the separate qualitative and quantitative samples. An ideal mixed-methods design should draw a qualitative sample, on conceptual grounds, from a large-scale representative panel study on recently immigrated individuals including comprehensive retrospective and current information-a challenging but worthwhile endeavour for future research.

\section{Acknowledgments}

We would like to thank the reviewers and Thomas Faist for helpful comments as well as the Deutsche 
Forschungsgemeinschaft (DFG) for funding the research project (616892) on which this article is based, "Transnational Educational Biographies: Self-Selection and Institutional Selection of Adult Immigrants into Education."

\section{Conflict of Interests}

The authors declare no conflict of interests.

\section{References}

Adamo, S., \& Binder, T. (2018). Union citizens and the recognition of professional qualifications: Where do we go from here? In S. de Vries, E. Ioriatti, P. Guarda, \& E. Pulice (Eds.), EU citizens' economic rights in action. Re-thinking legal and factual barriers in the internal market. Cheltenham: Edward Elgar Publishing.

Adamuti-Trache, M. (2011). First 4 years in Canada: Post-secondary education pathways of highly educated immigrants. Journal of International Migration and Integration, 12, 61-83. https://doi.org/10.1007/ s12134-010-0164-2

Aleksynska, M., \& Tritah, A. (2013). Occupationeducation mismatch of immigrant workers in Europe: Context and policies. Economics of Education Review, 36, 229-244. https://doi.org/10.1016/ j.econedurev.2013.06.001

Autorengruppe Bildungsberichterstattung. (Eds.). (2018). Bildung in Deutschland 2018 [Education in Germany 2018]. Bielefeld: wbv Publikation.

BMBF. (2020). Report on the recognition act 2019. Berlin: Bundesamt für Migration und Flüchtlinge.

Blossfeld, H.-P., Roßbach, H.-G., \& von Maurice, J. (Eds.). (2011). Education as a lifelong process-The German national educational panel study (NEPS). Wiesbaden: Springer.

Bohlinger, S. (2012). Internationale Standardklassifikation im Bildungswesen [International standard classification in the education system] (BWP No. 4). Bonn: BiBB.

Bonin, H., Boockmann, B., Brändle, T., Bredtmann, J., Brussig, M., Dorner, M., . . . Wolf, K. (2020). Begleitevaluation der arbeitsmarktpolitischen Integrationsmaßnahmen für Geflüchtete. Forschungsbericht 546 [Evaluation of labour-market policy programs for the integration of refugees. Research Report No.546]. Berlin: Bundesministerium für Arbeit und Soziales.

Davia, M. A., McGuinness, S., \& O'Connell, P. J. (2017). Determinants of regional differences in rates of overeducation in Europe. Social Science Research, 63, 67-80. https://doi.org/10.1016/ j.ssresearch.2016.09.009

Deppermann, A. (2015). Positioning. In A. de Fina \& A. Georgakopoulou (Eds.), The handbook of narrative analysis (pp. 369-387). Chichester: Wiley Blackwell.

Di Stasio, V., Bol, T., \& van de Werfhorst, H. G.
(2016). What makes education positional? Institutions, overeducation and the competition for jobs. Research in Social Stratification and Mobility, 43(Suppl. C), 53-63. https://doi.org/10.1016/j.rssm. 2015.09.005

DiPrete, T. A., Eller, C. C., Bol, T., \& van de Werfhorst, H. G. (2017). School-to-work linkages in the United States, Germany, and France. American Journal of Sociology, 122(6), 1869-1938. https://doi.org/10.1086/691327

Faist, T. (2016). Cross-border migration and social inequalities. Annual Review of Sociology, 42(1), 323-346. https://doi.org/10.1146/annurev-soc081715-074302

Haupt, A. (2016). Erhöhen berufliche Lizenzen Verdienste und die Verdienstungleichheit? [Do occupational licenses increase wages and wage inequality?]. Zeitschrift für Soziologie, 45(1), 39-56. https://doi. org/10.1515/zfsoz-2015-1002

Kanas, A., \& van Tubergen, F. (2009). The impact of origin and host country schooling on the economic performance of immigrants. Social Forces, 88(2), 893-915. https://doi.org/10.1353/sof.0.0269

Kogan, I. (2012). Potenziale nutzen! Determinanten und Konsequenzen der Anerkennung von Bildungsabschlüssen bei Zuwanderern aus der ehemaligen Sowjetunion in Deutschland [Determinants and consequences of the recognition of education among immigrants from the former Soviet Union in Germany]. Kölner Zeitschrift für Soziologie und Sozialpsychologie, 64(1), 67-89. https://doi.org/10.1007/s11577012-0157-6

Kruppe, T., \& Trepesch, M. (2017). Weiterbildungsbeteiligung in Deutschland. Auswertungen mit den Daten der Erwachsenenbefragung des Nationalen Bildungspanels "Bildung im Erwachsenenalter und lebenslanges Lernen" [Participation in further education in Germany. An analysis of the adult survey of the national educational panel study "Learning in adulthood and life-long learning"] (IAB Discussion Paper 16/2017). Nuremberg: IAB.

Liebau, E., \& Romiti, A. (2014). Migranten investieren in Sprache und Bildung. Bildungsbiografien von Zuwanderern nach Deutschland [Migrants invest into langugae and education. Educational biographies of migrants in Germany] (IAB Discussion Paper 21.2/2014). Nuremberg: IAB.

Liebau, E., \& Salikutluk, Z. (2016). Viele Geflüchtete brachten Berufserfahrung mit, aber nur ein Teil einen Berufsabschluss [Many refugees brought along occupational experience, but only part of them an occupational degree] (DIW Report No. 35). Berlin: German Institute for Economic Research.

LIfBi. (2016). Starting cohort 6: Adults (SC6). SUF version 7.0.0, codebook(en). Bamberg: LifBi-Leibniz Institute for Educational Trajectories.

NEPS. (2020). NEPS starting cohort 6-Adults, scientific use file (version 11.0.0) [Data set]. https://doi.org/ 10.5157/NEPS:SC6:11.0.0 
Nohl, A.-M. (2010). Von der Bildung zum kulturellen Kapital: Die Akkreditierung ausländischer Hochschulabschlüss auf deutschen und kanadischen Arbeitsmärkten [From education to cultural capital: Accrediting foreign tertiary degrees an the German and Canadian labour market]. In A.-M. Nohl, K. Schittenhelm, O. Schmidtke, \& A. Weiß (Eds.), Kulturelles Kapital in der Migration [Cultural capital in migration] (pp. 153-165). Wiesbaden: VS Verlag für Sozialwissenschaften.

Nohl, A.-M., Schittenhelm, K., Schmidtke, O., \& Weiß, A. (Eds.). (2014). Work in transition. Cultural capital and highly skilled migrants' passages into the labour market. Toronto: University of Toronto Press.

Povrzanović Frykman, M. (2009). Views from within: Bosnian refugees' experience related to their employment in Sweden. In P. Bevelander, M. Hagström, \& S. Rönnqvist (Eds.), Resettled and included? The employment integration of resettled refugees in Sweden (pp. 80-128). Malmö: Malmö University.

Prekodravac, M. (2020). Grenzjustierungen-Zwischen Qualifikation und Re-Qualifizierung: Biografische und institutionelle Rekonstruktionen von Bildungsverläufen erwachsener Zugewanderter in Deutschland [Adjusting boundaries. Between qualification and re-qualification: Biographical and institutional re-constructions of adult immigrants' educational trajectories in Germany]. Doctoral dissertation in preparation.

Protsch, P., \& Solga, H. (2016). The social stratification of the German VET system. Journal of Education and Work, 29(6), 637-661. https://doi.org/10.1080/ 13639080.2015.1024643

Pütz, R., Kontos, M., Larsen, C., Rand, S., \& RuokonenEngler, M.-K. (2019). Betriebliche Integration von Pflegekräften aus dem Ausland [Occupational integration of nurses from abroad]. Düsseldorf: Hans Böckler Stifung.

Reyneri, E., \& Fullin, G. (2011). Ethnic penalties in the transition to and from unemployment: A West European perspective. International Journal of Comparative Sociology, 52(4), 247-263. https://doi.org/ 10.1177/2F0020715211412114

Rosenthal, G. (2018). Interpretive social research. Göttingen: Göttingen University Press.

Rye, J. F. (2019). Transnational spaces of class: International migrants' multilocal, inconsistent and instable class positions. Current Sociology, 67(1), 27-46. https://doi.org/10.1177/0011392118793676

Sacchia, S., Kriesib, I., \& Buchmannca, M. (2016). Occupational mobility chains and the role of job opportunities for upward, lateral and downward mobility in Switzerland. Research in Social Stratification and Mobility, 44, 10-21. https://doi.org/10.1016/j.rssm. 2015.12.001

Schammann, H., \& Younso, C. (2016). Studium nach der Flucht? Angebote deutscher Hochschulen für Studieninteressierte mit Fluchterfahrung [Tertiary education for refugees? German university programs for refugees interested in enrolling in higher education]. Hildesheim: Hildesheim University Press.

Schittenhelm, K. (2018). Migration, Wissen und Ungleichheit. Grenzziehungen und Anerkennungsverhältnisse im Kontext wechselnder sozialer Felder [Migration, knowledge, and inequality: Boundary making and relations of recognition in the context of varying social fields]. In L. Behrmann, F. Eckert, A. Gefken, \& P. A. Berger (Eds.), Doing inequality (pp. 257-283). Wiesbaden: Springer Fachmedien.

Schofer, E., \& Meyer, J. W. (2005). The worldwide expansion of higher education in the twentieth century. American Sociological Review, 70, 898-920. https:// doi.org/10.1177/2F000312240507000602

Söhn, J. (2016). Back to school in a new country? The educational participation of adult immigrants in a lifecourse perspective. Journal of International Migration and Integration, 17(1), 193-214. https://doi. org/10.1007/s12134-014-0401-1

Söhn, J. (2019). Initial employment pathways of immigrants in Germany. Why legal contexts of reception matter-An analysis of life-course data. Transfer: European Review of Labour and Research, 25(1), 43-62. https://doi.org/10.1177/1024258918818069

Sommer, I. (2015). Die Gewalt des kollektiven Besserwissens. Kämpfe um die Anerkennung ausländischer Berufsqualifikationen in Deutschland [The violence of collective know-it-all. Struggles about recognition of occupational qualifications in Germany]. Bielefeld: transcript.

Spence, M. (1973). Job market signaling. Quarterly Journal of Economics, 87(3), 355-374. https://doi.org/ $10.2307 / 1882010$

Szewczyk, A. (2014). Continuation or switching? Career patterns of Polish graduate migrants in England. Journal of Ethnic and Migration Studies, 40(5), 847-864. https://doi.org/10.1080/1369183X.2013.831546

Themelis, S. (2008). Meritocracy through education and social mobility in post-war Britain: A critical examination. British Journal of Sociology of Education, 29(5), 427-438. https://doi.org/10.1080/ 01425690802263601

Tucci, I., Fröhlich, J. J., \& Stock, I. (2021). Exploring the nexus between migration and social positions using a mixed methods approach. Social Inclusion, 9(1), 114-129.

van Tubergen, F., \& van de Werfhorst, H. (2007). Postimmigration investments in education: A study of immigrants in the Netherlands. Demography, 44(4), 285-313. https://doi.org/10.1353/dem.2007.0046

Weber, M. (1980). Wirtschaft und Gesellschaft: Grundriss der verstehenden Soziologie [Economy and society: An outline of interpretive sociology]. Tübingen: Mohr. (Original work published 1922)

Weiß, A. (2005). The transnationalization of social inequality: Conceptualizing social positions on a world scale. Current Sociology, 53(4), 707-728. https://doi.org/10.1177/0011392105052722 


\section{About the Authors}

Janina Söhn (PhD) has worked as a Senior Researcher at the SOFI Göttingen since 2012. She attained her doctorate in Sociology at FU Berlin and worked at the Social Science Research Center Berlin (WZB) for several years. She was the principal investigator of the project this contribution is based on and has published on social inequality in education, employment, and retirement, immigrants' legal status, and migration and integration policy. Her quantitative methods specialize in longitudinal life-course analysis.

Milena Prekodravac (Master of Arts) has been a researcher at the SOFI Göttingen since 2015 where she finished her $\mathrm{PhD}$ thesis on educational biographies of recently immigrated adults, in 2020. She studied Social Anthropology and Gender Studies at Ruhr-University Bochum and was part of a collaborative research center at Bielefeld University. Her interests include qualitative social research, migration, and educational sociology. She currently works on corporate co-determination and societal perceptions of workers in Germany's metal industry. 